\title{
PEMAHAMAN TENTANG SOSIALISASI GENDER PADA SISWA SMA DI JAKARTA
}

\author{
Maria Tri Warmiyati ${ }^{1}$, Sri Hapsari Wijayanti ${ }^{2}$, Syarief Darmoyo ${ }^{3}$ \\ ${ }^{1}$ Fakultas Psikologi, Universitas Katolik Indonesia Atma Jaya Jakarta \\ maria.triwarmiyati@atmajaya.ac.id \\ ${ }^{2}$ Fakultas Ekonomi dan Bisnis, Universitas Katolik Indonesia Atma Jaya Jakarta \\ sri.hapsari@atmajaya.ac.id \\ ${ }^{3}$ Fakultas Ekonomi dan Bisnis, Universitas Katolik Indonesia Atma Jaya Jakarta \\ syarief.darmoyo@atmajaya.ac.id
}

\begin{abstract}
ABSTRAK
Peran agen sosialisasi terlihat memiliki hubungan pada internalisasi nilai gendernya. Sosialisasi gender dibantu oleh peran agen sosialisasi antara lain melalui keluarga, sekolah, teman bermain, budaya agama, budaya etnisitas, dan budaya institusi komunitas. Di sekolah, remaja menginternalisasi nilai feminitas dan maskulinitas dalam hal prestasi, bagi perempuan dapat terjadi konflik feminitas. Penelitian ini bertujuan untuk melihat pemahaman siswa SMA di Jakarta terhadap sosialisasi gender pada baik laki-laki maupun perempuan dari pengetahuan, persepsi diri, preferensi, dan perilaku dalam mengekspresikan gendernya. Penelitian dilakukan pada 221 sampel dari enam SMA di lima wilayah DKI Jakarta. Penelitian ini menemukan bahwa pengetahuan, persepsi diri, preferensi, dan perilaku laki-laki dan perempuan dari kelompok sosial-ekonomi menengah bawah dan menengah atas dalam mengekspresikan gendernya sesuai dengan sosialisai gender yang berlaku di masyarakat. Laki-laki lebih memilih dekat dengan figur kekasih dibandingkan teman, sedangkan perempuan lebih memilih dekat dengan figur teman dibandingkan figur kekasih.
\end{abstract}

Kata kunci: sosialisasi gender, feminin, maskulin,perilaku

\section{PENDAHULUAN}

\section{Latar Belakang}

Ketika mengamati kasus kekerasan remaja, menurut Marc Ross (dalam Fisher, 2000), perlu dipahami nilai-nilai sosial, norma-norma, praktik-praktik yang diterima, dan pihak-pihak yang terlibat dalam situasi tersebut. Alasan yang sering dipahami memperlihatkan bahwa kekerasan remaja diamati sebagai kenakalan remaja atau sebagai perilaku yang menyimpang. Dari sisi kacamata remaja sebagai subjek, pelaku merasa bahwa tindakannya ini sebagai ungkapan aspirasi mereka karena sering diperlakukan secara tidak adil. Mereka mencoba mencari kesempatan untuk mengungkapkan keinginannya di lingkungan rumah, di sekolah, bahkan di jalanan.

Pemahaman kekerasan pada remaja dalam perspektif gender berarti melihat konflik lebih dalam daripada sekadar yang terlihat oleh kacamata publik, bahkan pada tingkat yang lebih dalam lagi, yakni keluarga dan kelompok komunitasnya, seperti pernyataan Emma Watson aktor Inggris dan Goodwill Ambasador perempuan untuk PBB (dalam Cole, 2015):

..tidak sering bicara tentang laki-laki yang dipenjara oleh stereotip gender, tapi aku bisa melihat bahwa mereka, dan ketika mereka bebas, hal-hal akan berubah bagi perempuan sebagai konsekuensi alami. Jika laki-laki tidak harus agresif agar dapat diterima, perempuan tidak akan merasa terdorong untuk tunduk. Jika laki-laki tidak harus mengontrol, perempuan tidak perlu dikontrol.

Pemahaman identitas gender diperoleh sejak anak masih dalam kandungan. Keluarga sudah menyiapkan perlengkapan bayi sesuai dengan jenis kelaminnya. Jika anaknya laki-laki, akan disiapkan perlengkapan dengan nuansa biru, tetapi jika anaknya perempuan, akan dipilihkan warna merah muda. Pada masa kanak-kanak, permainan yang dipilihkan untuk perempuan cenderung berupa boneka, alat-alat masak, sementara laki-laki permainan robot-robotan, 
mobil-mobilan, atau pistol-pistolan. Larangan yang diberikan pada anak laki-laki sejak kecil, misalnya, tidak boleh cengeng karena laki-laki harus kuat, sementara anak perempuan tidak boleh bermain dengan memanjat. Anak perempuan tidak diperhatikan pendidikannya, tidak perlu sekolah terlalu tinggi, dilarang keluar malam, malahan dinikahkan sejak dini.

Di kalangan SMA, Dude dan Kau Fag (dalam Cole, 2015) telah melakukan penelitian bagaimana anak laki-laki disosialisasikan mengadopsi dan melakukan yang dominan, agresif, mengendalikan, dan versi seksual maskulinitas. Hasil temuannya adalah walaupun ada kekuatan sosial lainnya yang berpengaruh, kekuatan sosialisasi yang kuat dari gagasan dominan maskulinitas merupakan kontributor kunci untuk tingkat luas kekerasan seksual dan kekerasan terhadap perempuan dan anak perempuan.Seperti Siregar dan Rochani (2010), Suci (2012) menemukan juga bahwa mayoritas pelaku bullying di SMA adalah perempuan. Temuannya ini bertentangan dengan asumsi umum bahwa biasanya pelaku agresi adalah lakilaki. Hal ini dapat terjadi karena indikator perilaku bullies yang muncul cenderung verbal.

Dalam konteks di Indonesia, Siregar dan Rochani (2010) menggunakan sampel 200 siswa dari lima SMA di Jakarta, dengan pengukuran skala sosialisasi peran gender dari Raffaeli dan Ontai (2004). Kedua peneliti menemukan bahwa 56.4\% siswa laki-laki dan $84.9 \%$ perempuan mengatakan ibu adalah tokoh yang mengajari cara berperilaku sesuai dengan gender (h. 144); ibu adalah orangtua yang paling dominan dalam keluarga (73.5\%) Simpulan penelitian mereka adalah tidak ada hubungan antara sosialisasi gender oleh orangtua dan prasangka gender secara umum dan penerimaan gender pada remaja laki-laki dan perempuan. Selain itu, sosialisasi gender oleh orangtua memiliki hubungan dengan penolakan gender pada siswa laki-laki.

Menurut Oakley (1972) gender adalah perbedaan yang bukan biologis dan bukan kodrat Tuhan, perbedaan perilaku (behavioral differences) antara laki-laki dan perempuan yang dikonstruksi secara sosial melalui proses sosial dan kultural yang panjang (Fakih, 1999). Isu gerakan sosialisasi gender di Indonesia telah dimulai pada era 60-an, tetapi baru hangat dibicarakan pada tahun 70-an ketika masa kepemimpinan Soeharto (Tim Peneliti PSW, 2005). Sosialisasi gender menurut Mackie (1991) merupakan suatu bagian dari sosialisasi pada umumnya, melibatkan proses saat individu belajar untuk menjadi feminin dan maskulin sesuai dengan harapan saat ini dalam masyarakatnya. Sosialisasi gender sebagai proses seumur hidup yang dimulai dengan sosialisasi primer, sebagai pengenalan awal masuk dalam lingkungan sosialnya pada masa kanak-kanak (chilhood) dan masa remaja (adolescence) dan dilanjutkan dengan sosialisasi sekunder.

Lebih lanjut dikatakan Mackie (1991), sosialisasi primer melibatkan perkembangan bahasa dan identitas individu; pembelajaran keterampilan kognitif dan kontrol diri; internalisasi standar moral dan sikap yang sesuai; pemahaman tentang peran sosialnya. Sosialisasi ini terjadi pada hubungan emosional dengan orang-orang yang terdekat (significant others).

Sosialisasi gender dibantu oleh peran agen sosialisasi antara lain melalui keluarga, sekolah, teman bermain, budaya agama, budaya etnisitas, dan budaya institusi komunitas. Di sekolah, remaja menginternalisasi nilai feminitas dan maskulinitas dalam hal prestasi, bagi perempuan dapat terjadi konflik feminitas. Bowerman (dalam Hyde, 2007) menjelaskan bahwa sejak kecil, anak perempuan dan laki-laki ditekankan untuk belajar dan memiliki nilai yang baik di sekolah atau berprestasi. Namun, khusus untuk remaja perempuan, jika perempuan terus berprestasi,ia cenderung kurang feminin, karena prestasi dalam sekolah dan bidang lain yang tidak berhubungan dengan rumah tangga kurang tepat untuk perempuan. Hal ini membuat 
remaja perempuan mengalami konflik, karena di satu sisi ia ingin mengekspresikan diri sebagai seseorang yang produktif dan hal ini dapat dicapai melalui prestasi, tetapi di sisi lain ia juga ingin menampilkan diri sebagai seorang perempuan yang baik untuk mematuhi harapan peran gender dan menjadi feminin.

Peran agen sosialisasi terlihat memiliki hubungan pada internalisasi nilai gendernya. Mackie (1991) menemukan bahwa anak yang memiliki latar belakang keluarga yang tidak bekerja, keluarga yang terlibat tindakan kriminal, keluarga yang bercerai, kedua orang tua bekerja, keluarga dengan penggunaan narkoba, akan mengganggu fungsi sosialisasi nilai-nilai trasidisional.

\section{Rumusan Masalah}

Bagaimanakah pemahaman siswa SMA di Jakarta mengenai sosialisasi gender pada baik laki-laki maupun perempuan dari pengetahuan, persepsi diri, preferensi, dan perilaku dalam mengekspresikan gendernya?

\section{METODE PENELITIAN \\ Sampel Penelitian}

Penelitian dilakukan pada 221 sampel dari enam Sekolah Menengah Atas (SMA) di lima 5 wilayah DKI Jakarta. Karakteristik sampel penelitian terdiri atas remaja SMA, berjenis kelamin laki-laki dan perempuan, berusia 14 - 18 tahun.

\section{Teknik Pengambilan Sampel}

Teknik pengambilan sampel menggunakan teknik convenience sampling. Penelitian ini menggunakan kuesioner sebagai alat pengumpulan datanya. Penelitian ini mengacu pada skema Sosialisasi Gender dari Huston (1983) dalam Mackie (1991) The Content of Gender Socialization yang diukur melalui domain sex/gender, activities and interest, personal and social attributes, gender-based social relationships, dan stylistic and symbolic content. Setiap domain berisi empat dimensi, yaitu concepts or beliefs, identity preferences, values (for self or others), dan general expression. Sebelum disebarkan, kuesioner tersebut diuji validitas dan reliabilitasnya. Untuk data nominal, pengujian validitas dilakukan dengan teknik point-biserial correlation dan pengujian reliabilitas dengan metode Kuder-Richardson 20. Untuk data interval, pengujian validitas dilakukan dengan teknik pearson product-moment dan pengujian reliabilitas dengan metode Cronbach Alpha. Hasil uji validitas menunjukkan semua item pertanyaan valid $(\mathrm{p}<0.05)$ dan hasil uji reliabilitas menunjukkan semua variabel penelitian reliabel (nilai Cronbach' Alpha dan KR-20 > 0.7)

\section{Teknik Analisis Data}

Data penelitian ini dianalisis dengan crosstabs dan uji Kruskal-Wallis dan One-Way Anova. Crosstabs digunakan untuk menggambarkan karakteristik responden, sementara uji KruskalWallis dan One-Way Anova digunakan untuk membandingkan perbedaan mean skor antara kelompok laki-laki yang menjawab pertanyaan tentang laki-laki, kelompok laki-laki yang menjawab pertanyaan tentang perempuan, kelompok perempuan yang menjawab pertanyaan tentang perempuan, dan kelompok perempuan yang menjawab pertanyaan tentang laki-laki, dan juga untuk membandingkan perbedaan mean skor antara kelompok teman, figur otoritas, dan relasi romantis. Semua proses analisis data dalam penelitian dilakukan dengan bantuan program SPSS versi 20 dengan taraf signifikansi 0.05 . 


\section{HASIL DAN PEMBAHASAN}

Jumlah subjek penelitian ini 221 siswa yang terdiri atas laki-laki (48\%) dan subjek perempuan (52\%). Bila dilihat per status sosial ekonomi sekolah, jumlah subjek laki-laki lebih banyak bersekolah di SMA Menengah Atas (50,5\%) daripada jumlah subjek laki-laki yang bersekolah di SMA Menengah Bawah (45,6\%), sementara jumlah subjek perempuan lebih yang banyak bersekolah di SMA Menengah Bawah (54,4\%) dari jumlah subjek perempuan yang bersekolah di SMA Menengah Atas (49,5\%).

Pekerjaan ayah responden cukup beragam. Ada yang bekerja sebagai pegawai negeri sipil, TNI/Polri, pegawai swasta, wirausahawan, dokter, dan sebagainya. Dari berbagai pekerjaan ini, tampaknya pegawai swasta $(35,9 \%)$ dan wirausahawan $(30,1 \%)$ merupakan dua jenis pekerjaan yang banyak dimiliki oleh ayah responden. Seperti juga pekerjaan ayah subjek, pekerjaan ibu subjek juga cukup beragam. Meskipun demikian, tampaknya ibu rumah tangga $(64,3 \%)$ merupakan jenis pekerjaan yang paling banyak dimiliki oleh responden, yang menjadi wirausahawan $(10,2 \%)$, yang bekerja sebagai pegawai negeri sipil $(8,3 \%)$.

Tabel 1

Uji Beda Berdasarkan Jenis Kelamin dengan Kruskal-Wallis dan One-Way Anova

\begin{tabular}{|c|c|c|c|c|c|c|}
\hline \multirow{2}{*}{ Subdomain } & \multicolumn{4}{|c|}{ Mean Skor } & \multirow{2}{*}{$\begin{array}{c}\text { Kruskal- } \\
\text { Wallis }\end{array}$} & \multirow{2}{*}{$\begin{array}{c}\text { One-Way } \\
\text { Anova }\end{array}$} \\
\hline & MM & MF & FM & FF & & \\
\hline
\end{tabular}

Kelompok sosial-ekonomi menengah ke bawah

Sex Gender

$\begin{array}{lllll}\text { Concept or belief } & 1.04(0.49) & 1.72(0.65) & 0.9(0.6) & 1.94(0.5)\end{array} \quad 85.887 * * *$

Activity and interest

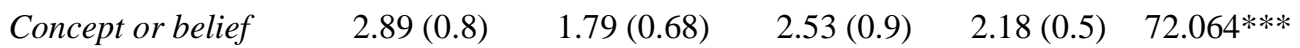

Personal social attributes

Preferences values

$25.34(3.12)$

$19.66(3.68)$

$24.44(3.46) \quad 25.15(3.69)$

$31.791 * * *$

Gender expression

$10.36(2.34)$

$11.74(2.86)$

$9.53(2.3)$

$16(2.44)$

$115.89 * * *$

Kelompok sosial-ekonomi menengah ke atas

Sex/ gender

$\begin{array}{llllll}\text { Concept or belief }) & 0.79(0.34) & 2.08(0.66) & 0.94(0.36) & 1.85(0.62) & 105.962 * * * \\ \text { Concept or belief } & 2.66(2.00) & 1.91(0.70) & 2.53(0.90) & 2.21(0.80 & 35.129 * * *\end{array}$

Personal social attributes

$\begin{array}{llllll}\text { Preferences values }) & 25.66(4.40) & 20.04(3.22) & 24.23(3.64) & 24.3(4.44) & - \\ \text { Gender expression } & 9.96(2.23) & 12.94(2.15) & 9.45(2.24) & 15.13(2.85) & 102.684 * * *\end{array}$
maskulin, (FF) perempuan menjawab feminin; $* \rho<0.05, * * \rho<0.01, * * * \rho<0.001$

Tabel 1 menunjukkan hasil uji beda (Kruskal-Wallis dan One-way Anova) yang dilakukan pada kelompok laki-laki dan perempuan di kelompok sosial-ekonomi menengah bawah dan menengah atas. Dari tabel tersebut, diketahui bahwa semua subdomain memiliki hasil yang berbeda secara signifikan antara kelompok laki-laki dan perempuan ( $p$-value untuk semua 
subdomain < 0.05). Dengan demikian, dapat disimpulkan bahwa sebagian besar pengetahuan, persepsi diri, preferensi, dan perilaku dalam mengekspresikan gendernya sudah sesuai dengan norma yang berlaku di masyarakat. Kesadaran identitas gender diperoleh dari lingkungan bahwa lingkungkanlah yang mengajarkan ia anak laki-laki atau anak perempuan (Sadli, 2010).

Pada kelompok sosial-ekonomi menengah ke bawah, skor laki-laki $(\mathrm{M}=1.04)$ lebih besar signifikan $(\mathrm{p}<0.05)$ dibandingkan skor perempuan $(\mathrm{M}=0.9)$ pada soal mengenai perilaku maskulin yang berkaitan dengan pengetahuan terhadap gender, namun lebih kecil daripada skor laki-laki pada soal feminin ( $M=1.72)$. Sebaliknya, skor perempuan $(M=1.94)$ lebih besar signifikan $(\mathrm{p}<0.05)$ dibandingkan skor laki-laki $(\mathrm{M}=1.72)$ pada soal mengenai perilaku feminin dan skor perempuan pada soal maskulin (0.9). Adapun pada kelompok sosialekonomi menengah ke atas, skor kelompok laki-laki $(M=0.79)$ lebih kecil signifikan $(p<0.05)$ dibandingkan skor kelompok perempuan $(\mathrm{M}=0.94)$ pada soal mengenai perilaku maskulin dan skor laki-laki $(\mathrm{M}=2.08)$ pada soal feminin terkait pengetahuan terhadap gender. Pada soal feminin, skor perempuan $(\mathrm{M}=1.85)$ juga lebih kecil signifikan $(\mathrm{p}<0.05)$ daripada skor lakilaki $(M=2.08)$ dan lebih besar daripada skor perempuan $(M=0.94)$ pada soal maskulin. Hal ini berarti pada kelompok sosial-ekonomi menengah-bawah memperlihatkan bahwa responden penelitian ini sudah memahami stereotipe mengenai yang pantas dan tidak pantas bagi perempuan atau, laki-laki, misalnya tato pantas untuk laki-laki, bukan perempuan, operasi plastik untuk perempuan, bukan laki-laki. Dalam hal pakaian, akesoris lebih pantas digunakan perempuan. Dalam hal permainan, baik laki-laki maupun perempuan menyukai permainan games online. Bedanya laki-laki menyukai game online bertema petualangan, kekerasan, dan kompetisi, sementara bertema tentang fashion, memasak, tata rias. Seperti dikatakan Ambert dalam Mackie (1991), "boys toys... encourage rougher play, activity, creativity, mastery, and curiosity; girls toys, on the other hand, encourange passivity, observation, simple behavior, and solidarity play". Sedangkan, pada kelompok sosialekonomi menengah-atas polanya berbeda. Misalnya, operasi plastik bukan hanya untuk perempuan saja, tetapi juga laki-laki. Dalam hal permainan game online, perempuan tidak hanya memilih permainan yang bertemakan tentang fashion, memasak, tata rias, tetapi juga petualangan, kekerasan, dan kompetisi.

Pada kelompok sosial-ekonomi menengah ke bawah, pada soal mengenai perilaku maskulin yang berkaitan dengan pengetahuan terhadap aktivitas dan minat sesuai gendernya (pekerjaan, permainan), skor laki-laki $(\mathrm{M}=2.89)$ lebih besar signifikan $(\mathrm{p}<0.05)$ dibandingkan skor perempuan $(\mathrm{M}=2.53)$ pada soal maskulin dan skor laki-laki pada soal feminine $(\mathrm{M}=1.79)$. Skor perempuan $(\mathrm{M}=2.18)$ pada soal feminin juga lebih besar signifikan $(\mathrm{p}<0.05)$ dibandingkan skor laki-laki pada soal feminin $(\mathrm{M}=1.79)$, tetapi lebih kecil signifikan $(\mathrm{p}<0.05)$ dibandingkan skor perempuan $(\mathrm{M}=2.53)$ pada soal maskulin. Adapun pada kelompok sosial-ekonomi menengah ke atas, pada soal mengenai perilaku maskulin yang berkaitan dengan pengetahuan terhadap aktivitas dan minat sesuai gendernya (permainan, pekerjaan), skor laki-laki $(\mathrm{M}=2.66)$ pada soal maskulin lebih besar signifikan $(\mathrm{p}<0.05)$ dibandingkan skor perempuan $(\mathrm{M}=2.53)$ pada soal maskulin dan skor laki-laki $(\mathrm{M}=1.91)$ pada soal feminin. Skor perempuan $(\mathrm{M}=2.21)$ pada soal feminin tidak berbeda secara signifikan $(\mathrm{p}<0.05)$ baik dengan skor laki-laki $(\mathrm{M}=1.91)$ pada soal feminin maupun skor perempuan $(\mathrm{M}=2.53)$ pada soal maskulin. Hal ini memperlihatkan baik kelompok sosialekonomi menengah-bawah maupun menengah-atas memandang bahwa laki-laki lebih cocok dengan pekerjaan kasar atau teknisi, sedangkan perempuan cocok dengan pekerjaan mendidik (guru), merawat kesehatan (bidan). Seperti yang ditekankan Mackie (1991) bahwa peluang 
pekerjaan untuk anak-anak di luar rumah dan masyarakat dibedakan berdasarkan jenis kelamin. Menurut Mackie (1991), sejak dini laki-laki sudah diperlakukan berbeda dari perempuan. Laki-laki dibiasakan untuk bersikap kasar, sedangkan perempuan lemah lembut. Laki-laki tidak banyak bicara, sedangkan perempuan lebih banyak bicara. Perempuan banyak melakukan pekerjaan domestik, sedangkan laki-laki lebih banyak beraktivitas di luar rumah.

Pada kelompok sosial-ekonomi menengah ke bawah, untuk soal yang berkaitan dengan cara menyikapi kepribadian dan perilaku orang lain, skor laki-laki $(\mathrm{M}=25.34)$ pada soal maskulin dan skor perempuan $(\mathrm{M}=25.15)$ pada soal feminin lebih besar signifikan $(\mathrm{p}<0.05)$ dibandingkan skor laki-laki $(\mathrm{M}=19.66)$ pada soal feminin. Kedua skor tersebut juga tidak berbeda signifikan ( $\mathrm{p}>0.05)$ dibandingkan dengan skor perempuan $(\mathrm{M}=24.66)$ pada soal maskulin. Adapun pada kelompok sosial-ekonomi menengah ke atas, dalam menyikapi kepribadian dan perilaku orang lain, skor laki-laki $(\mathrm{M}=25.66)$ pada soal maskulin dan skor perempuan $(\mathrm{M}=24.3)$ pada soal feminin lebih besar signifikan $(\mathrm{p}<0.05)$ dibandingkan skor laki-laki $(M=20.04)$ pada soal feminin. Kedua skor tersebut juga tidak berbeda signifikan $(\mathrm{P}>0.05)$ dibandingkan dengan skor perempuan $(\mathrm{M}=24.23)$ pada soal maskulin. Temuan ini menunjukkan bahwa kelompok sosial-ekonomi menengah-bawah dan menengah-atas, ketika berhadapan dengan masalah, untuk responden perempuan lebih memilih mengungkapkan perasaannya (menangis), kesulitan jika dihadapkan pada sebuah pilihan, ikut merasakan penderitaan orang lain. Sebaliknya, responden laki-laki cenderung tidak mengungkapkan perasaan pada orang lain, mudah mengambil keputusan, tidak cepat larut dalam penderitaan orang lain. Hasil studi Edwards dan Williams (1980) menunjukkan bahwa anak-anak sudah mengenal stereotype laki-laki dan perempuan, misalnya, laki-laki memiliki sifat: agresif, kuat, keras, ambisius, kejam, kasar, sementara perempuan lemah, menghargai, sentimental, emosional. Menurut William dan Best dalam Mackie (1991), perbedaan laki-laki dan perempuan dalam cara menyikapi kepribadian dan perilaku orang lain karena anak perempuan sudah didik sedari kecil untuk memiliki sifat feminine seperti santun, ringan tangan, penuh pertimbangan, dll., sementara laki-laki memiliki sifat maskulin seperti mandiri, asertif, berpetualang, dll.

Pada kelompok sosial-ekonomi menengah ke bawah, dalam mengekspresikan gender untuk bersikap terhadap orang lain, skor laki-laki $(\mathrm{M}=10.36)$ lebih besar signifikan $(\mathrm{p}<0.05)$ dibandingkan skor perempuan $(M=9.53)$, tetapi tidak berbeda secara signifikan $(\mathrm{p}>0.05)$ dengan skor laki-laki (11.74) pada soal feminin. Akan tetapi, skor perempuan pada soal feminin $(M=16)$ lebih besar secara signifikan $(\mathrm{p}<0.05)$ dibandingkan skor perempuan $(M=9.53)$ pada soal maskulin dan skor laki-laki pada soal feminin $(M=1174)$. Adapun pada kelompok sosial-ekonomi menengah ke atas, dalam mengekspresikan gender untuk bersikap terhadap orang lain, skor laki-laki $(\mathrm{M}=9.96)$ pada soal maskulin lebih kecil signifikan dibandingkan skor laki-laki $(\mathrm{M}=12.94)$ pada soal feminin. Akan tetapi, skor perempuan $(\mathrm{M}=15.13)$ pada soal feminin lebih besar secara signifikan $(\mathrm{p}<0.05)$ dibandingkan skor perempuan $(\mathrm{M}=9.45)$ pada soal maskulin dan skor laki-laki (12.94) pada soal feminin. Hal ini berarti pada kelompok sosial-ekonomi menengah-bawah dan menengah-atas, responden lakilaki cenderung mengungkapkan pendapat sendiri, berkemauan keras, suka berada di lingkungan yang kotor, sementara responden perempuan cenderung mengikuti pendapat orang lain, kurang ada kemauan, tidak suka berada di lingkungan yang kotor. Menurut Mackie (1991), hal ini terjadi karena anak-anak mempelajari norma-norma tentang jenis kelamin atau gender yang kemudian diterapkan dalam kehidupan mereka sehari-hari. 
Tabel 2

Uji Beda Berdasarkan Kelompok Sosial-Ekonomi pada Item Netral dengan Kruskal-Wallis

\begin{tabular}{llll}
\multicolumn{3}{c}{ Mean Skor } & Kruskal-Wallis \\
\cline { 1 - 2 } Teman & Figur Otoritas & Relasi Romantis & \\
\hline
\end{tabular}

Kelompok Sosial-ekonomi menengah ke bawah

$\begin{array}{lllll}\text { Laki-laki } & 27.15(4.23) & 8.21(2.05) & 31.06(2.56) & 118.284^{* * *} \\ \text { Perempuan } & 29.31(5.31) & 10.13(2.28) & 27.18(3.78) & 125.885^{* * *}\end{array}$

Kelompok Sosial-ekonomi menengah ke atas

\begin{tabular}{|c|c|c|c|c|}
\hline Laki-laki & $13.62(3.64)$ & $11.7(1.31)$ & $22.96(3.69)$ & $99.057 * * *$ \\
\hline Perempuan & $27.75(7)$ & $10.21(1.99)$ & $25.32(4.08)$ & $105.160 * * *$ \\
\hline
\end{tabular}

Dari Tabel 2, dapat dilihat bahwa pernyataan-pernyataan mengenai kecenderungan kedekatan terhadap salah satu jenis kelamin dalam hubungan dengan figur-figur sosial. Figur-figur tersebut, yaitu teman, otoritas, dan kekasih. Kelompok laki-laki baik pada tingkat sosialekonomi menengah ke atas maupun menengah ke bawah, figur kekasih $(\mathrm{M}=22.96$ dan $\mathrm{M}=31.06)$ selalu lebih tinggi signifikan $(\mathrm{p}<0.05)$ daripada figur teman $(\mathrm{M}=13.6$ dan $M=27.15)$ dan figur teman juga lebih tinggi signifikan daripada figur otoritas $(M=11.21$ dan $\mathrm{M}=8.21$ ). Pada kelompok perempuan, baik pada tingkat sosial-ekonomi menengah ke atas maupun menengah ke bawah, figur otoritas $(M=11.7$ dan $M=10.13)$ tetap paling kecil nilainya. Akan tetapi, figur teman lebih tinggi $(M=27.75$ dan $M=29.31)$ signifikan $(\mathrm{p}<0.05)$ daripada figur kekasih (25.32 dan $\mathrm{M}=27.18)$ pada kelompok perempuan. Berdasarkan data tersebut, asumsi yang muncul adalah bahwa kelompok laki-laki lebih memilih dekat dengan figur kekasih dibandingkan teman, sedangkan perempuan lebih memilih dekat dengan figur teman dibandingkan figur kekasih. Temuan ini menunjukkan bahwa perilaku memilih mereka didasari oleh stereotype yang disosialisasi oleh lingkungan dan diinternalisasi oleh masing-masing jenis kelamin, seperti laki-laki harus kasar, kejam, agresif, ambisius, kuat, sementara perempuan harus lemah lembut, lemah, sentimental, emosional, pasif, menyenangkan (Mackie, 1991). Sadli (2010) juga menemukan bahwa perempuan berteman dengan perempuan dan laki-laki berteman dengan laki-laki, seperti anggapan umum bahwa perempuan harus cantik dan laki-laki jangan bermain dengan perempuan.

Dari uraian di atas dapat dilihat bahwa peran dan sifat laki-laki dan perempuan dibedakan. Menurut teori kebudayaan, perbedaan ini merupakan hasil konstruksi budaya (Muthali'in,2001). Karena kebudayaan berbeda-beda, maka peran dan sifat laki-laki berbeda antara kebudayaan yang satu dan kebudayaan yang lain sebagaimana yang diungkapkan oleh Wibawa \& Warmiyati (2011) bahwa "tidak ada konstruksi sosial yang sama persis dalam masyarakat yang satu dan masyarakat lainnya". Perbedaan peran dan sifat laki-laki dan perempuan ini disosialisasikan terus-menerus oleh agen-agen sosial. Siregar dan Rochani (2010) mengatakan bahwa sosialisasi gender dapat diperoleh siswa dari berbagai agen yang menjadi bagian dari lingkungannya. Agen-agen tersebut merupakan figur-figur yang menjadi preferensi dalam mengekspresikan gendernya, yang meliputi orangtua, teman, sekolah, budaya. Sejalan temuan dari Mackie (1991) bahwa sosialisasi gender dapat terjadi pada hubungan emosional dengan orang-orang yang terdekat (significant others). Dalam mensosialisasikan nilai-nilai gender, mereka menggunakan metode (i) pemahaman, yaitu 
menjelaskan sifat dan peranan sosial masing-masing gender, (ii) reward and punsihment, artinya memberikan ganjaran/hukuman bagi perilaku yang sesuai/tidak sesuai dengan norma yang berlaku di masyarakat, (iii) perlakuan/cara bersikap, dalam hal ini ketika menghadapi laki-laki dan perempuan, agen memiliki cara bersikap yang berbeda. Misalnya, ketika berbicara dengan perempuan, nada bicara agen lemah lembut, sebaliknya ketika berbicara dengan laki-laki nada bicara mereka keras dan tegas. Mereka akan mengikuti norma-norma ini dalam kehidupan sehari-hari karena jika tidak mengikuti norma standar ini, mereka takut tidak diterima oleh masyarakat (Sadli, 2010).

\section{SIMPULAN DAN SARAN}

Pengetahuan, persepsi diri, preferensi, dan perilaku laki-laki dan perempuan dari kelompok sosial-ekonomi menengah bawah dan menengah atas dalam mengekspresikan gendernya sesuai dengan sosialisai gender yang berlaku di masyarakat, kecuali untuk aspek pengetahuan terhadap gender pada kelompok sosial-ekonomi menengah atas polanya sedikit berbeda dengan kelompok-sosial ekonomi bawah. Hal ini karena kelompok sosial-ekonomi menengah atas memiliki akses yang lebih luas pada pengetahuan. Laki-laki lebih memilih dekat dengan figur kekasih dibandingkan teman, sedangkan perempuan lebih memilih dekat dengan figur teman dibandingkan figur kekasih. Hal ini terjadi karena hasil konstruksi budaya dan disosialisasikan terus-menerus oleh agen-agen sosialisasi.

Beberapa hal dapat disarankan bahwa penelitian ini hanya berfokus pada sosialisasi nilai-nilai gender. Oleh karena itu, penelitian selanjutnya diharapkan berfokus pada nilai-nilai kesetaraan gender dan agen-agen sosialisasinya. Hasil penelitian ini dapat digunakan sebagai acuan untuk menumbuhkan kesadaran nilai-nilai kesetaraan gender melalui pelatihanpelatihan baik untuk agen-agen sosialisasi maupun untuk para remaja, dan juga pelatihan pengarusutamaan gender bagi para pembuat kebijakan di bidang pendidikan, pekerja seni, penyusun buku.

\section{Ucapan Terima Kasih}

Kami mengucapkan terima kasih kepada LPPM-Unika Atma Jaya yang telah mendanai penelitian ini. Kami juga mengucapkan banyak terima kasih kepada pihak SMAN 8, SMAN 20, SMAS Labs School, SMAS BPK Penabur, SMAS Wijaya Kusuma, dan SMAS Cahaya Sakti di Jakarta yang telah bersedia berpartisipasi dan mengizinkan siswa-siswa untuk menjadi responden penelitian ini.

\section{REFERENSI}

Arfani, F (2013). Ratusan remaja menari massal tolak kekerasan perempuan Kesra. http://www.antarajatim.com/lihat3/berita/104527/ratusan-remaja-menari-massal-tolakkekerasan-perempuan diakses 20 Feb 2015.

Catatan akhir tahun 2011 Komisi Perlindungan Anak. https://komnaspa.wordpress.com/2011/12/21/catatan-akhir-tahun-2011-komisinasional-perlindungan-anak/ diakses $20 \mathrm{Feb} 2015$.

Cole, N. L. (2015) The Most important words in Emma Watson's speech were abaut masculinity: He for she challenges men and boys to embrace feminism.

Crawford, M. (2012) Transformations: Women, gender and psychology. 2nd ed. New York: Mc Graw Hill.

Fakih, M. (1999). Analisis gender dan transformasi sosial. Yogyakarta: Pustaka Pelajar.

Fisher, S. (2000). Mengelola konflik. Jakarta: The British Council, Indonesi. 
Glosari,Gender. (2011). http://www.kemenpppa.go.id/v3/index.php/glosari/gender. Diakses 12 Februari 2018.

Hyde, J. S. (2007). Half of the human experience: The psychology of women. ( $7^{\text {th }}$ ed.) New York: Houghton Mifflin Co.

Mackie, M. (1991). Gender relations in Canada. Vancauver: Butterworth.

Muthali'in, A. (2001). Bias gender dalam pendidikan. Surakarta: Muhammadiyah University.

Okin, S.M. (1999). Is multikulturalism bad for women? In Joshua C., Matthew H dan Martha C.N. (Eds.). New Jersey: Princeton University Press.

Sadli, S. (2010). Berbeda tetapi setara: Pemikiran tentang kajian perempuan. Jakarta: PT Gramedia.

Siregar, D. A. I. \& Rochani, S. (2010). Sosialisasi gender oleh orang tua dan prasangka gender pada remaja. Jurnal Psikologi, 3(2), 141-147.

Suci, E.S.T. dan Hilda, T.M. (2012). Pola attachment terhadap orang tua dan kaitannya dengan tendensi agresi pada siswa pelaku school bullying di SMU Jakarta. Manasa: Jurnal Ilmiah Psikologi, 1, 1 Juni, h. 90.

Tim Peneliti PSW UIN Sunan Kalijaga Yogyakarta. (2005). Pola gerakan sosialisasi gender. laporan hasil penelitian. Media Perempuan Edisi 3, h. 9-12.

Wibawa, D.S. dan Warmiyati, M.M.T. (2011). Perempuan dalam lingkungan sosiakulturalnya: Konstruksi sosial hasil bentukan budaya. Dalam Psikologi Perempuan Pendekatan Kontekstual Indonesia. Jakarta: Penerbit Universitas Atma Jaya. 